\title{
コンクリートの熱物性および熱物性試験に関する一考察
}

\section{THERMAL PROPERTIES AND THE TEST METHODS OF CONCRETE}

\author{
秋田宏*・尾坂芳夫** \\ By Hiroshi AKITA and Yoshio OZAKA
}

\begin{abstract}
Conductivity, specific heat and diffusivity of concrete are considered in separate tests. Some peculiarity of the consideration are to investigate the relationship between the three quantities, to compare two methods of measuring conductivity and to compare wet and dry conditions.

Fairly good relationship of the measured three quantities both wet and dry conditions confirm the accuracy of the test data. It can be seen that comparison method gives $13 \%$ lower value of conductivity, and the test data shift by the specimen thickness and temperature setting. In spite of the faults, comparison method can be serviceable test method of concrete because of the capability of changing wetness and of its easy operation.

Keywords : concrete, thermal properties, test methods
\end{abstract}

\section{1. まえがき}

コンクリート構造物に生ずる温度応力や温度ひびわれ あるいは温度分布や通過熱量を問題とする際に, コンク リートの熱的性質について知る必要がある. しかし，コ ンクリートの熱的性質について述べた文献はあまり多く はなく，しかもそれらの文献にみられる物性值の間には 大きな幅がある。

熱伝導率を例に取ると, 文献 1）および 2) では, 試 験によらない場合に用いてよい一般的な值として, 2.5 および $2.3 \mathrm{~W} \cdot \mathrm{m}^{-1} \cdot \mathrm{K}^{-1}\left(2.2\right.$ および $2.0 \mathrm{kcal} \cdot \mathrm{m}^{-1} \cdot \mathrm{h}^{-1}$. $\left.{ }^{\circ} \mathrm{C}^{-1}\right)$ を挙げている. また, 文献 3)，4），5）では, $1.4 \sim 1.6 \mathrm{~W} \cdot \mathrm{m}^{-1} \cdot \mathrm{K}^{-1}\left(1.2 \sim 1.4 \mathrm{kcal} \cdot \mathrm{m}^{-1} \cdot \mathrm{h}^{-1} \cdot{ }^{\circ} \mathrm{C}^{-1}\right)$ の範囲を示しており, 文献 6) には $0.8 \sim 1.4 \mathrm{~W} \cdot \mathrm{m}^{-1}$. $\mathrm{K}^{-1}\left(0.7 \sim 1.2 \mathrm{kcal} \cdot \mathrm{m}^{-1} \cdot \mathrm{h}^{-1} \cdot{ }^{\circ} \mathrm{C}^{-1}\right)$ が示されている.

著者らがこれまでに PC 貯水タンクに使用されたコ ンクリートで実測した値は, $0.8 \sim 1.0 \mathrm{~W} \cdot \mathrm{m}^{-1} \cdot \mathrm{K}^{-1}(0.7$ $\left.\sim 0.9 \mathrm{kcal} \cdot \mathrm{m}^{-1} \cdot \mathrm{h}^{-1} \cdot{ }^{\circ} \mathrm{C}^{-1}\right)$ の範囲にあった ${ }^{7)}$.

もちろん，コンクリートの熱伝導率は使用骨材や配合

* 正会員 工修 東北工業大学助教授 土木工学科 ( 率982 仙台市八木山香澄町 35-1)

** 正会員 工博 東北大学教授 工学部土木工学科 （９882 仙台市荒巻字青葉）
あるいはコンクリートの含水状態や温度によっても変化 するので, 単に数値だけを比較したのでは不十分である. 文献 8) 11) では, 骨材の種類に応じ $1.5 \sim 3.6 \mathrm{~W} \cdot \mathrm{m}^{-1}$. $\mathrm{K}^{-1}\left(1.3 \sim 3.1 \mathrm{kcal} \cdot \mathrm{m}^{-1} \cdot \mathrm{h}^{-1} \cdot{ }^{\circ} \mathrm{C}^{-1}\right)$ の值が示されている. また徳田らは，骨材の種類と単位骨材量を変化させた多 くの実験を行い, 熱伝導率の変化について報告している

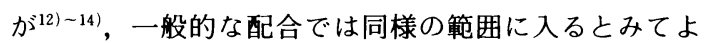
い. 著者らの実測は, 主として安山岩砕石を粗骨材とし たコンクリートで行われたので，骨材を安山岩に限定す ると文献 10$) ， 11 ）$ に, $1.98 \sim 2.27 \mathrm{~W} \cdot \mathrm{m}^{-1} \cdot \mathrm{K}^{-1}(1.70$ $\left.\sim 1.95 \mathrm{kcal} \cdot \mathrm{m}^{-1} \cdot \mathrm{h}^{-1} \cdot{ }^{\circ} \mathrm{C}^{-1}\right)$ の範囲が示されているが, 著者らの測定値はその半分程度である.たとえば，各種 コンクリート製容器の保温性・放熱性を知りたい場合に は, 通過熱量が熱伝導率に直接比例するため, 熱伝導率 の差が大きな問題となる.

したがって, 以下の 3 点

（1）著者らの熱伝導率測定結果が小さかった原因を 探ること

（2）文献 1)，2）で一般的な值としている熱伝導率 をそのまま用いることが, 安山岩を骨材とするコン クリートの場合にも妥当であるかどうかを調べるこ と

（3）コンクリートの熱物性試験法標準化に役立つ基 
礎資料を得ること

を目的とし，試験方法的な側面からの検討を試みた。す なわち, コンクリートの配合は 1 種類のみとしたが, 比 熱, 熱伝導率, 熱拡散率の試験を独立に行って, 試験値 相互の満足すべき関係から試験誤差を検討した。特に， 熱伝導率については，2 種類の試験方法による結果を比 較し, そのうち平板比較法については適用性の検討を 行った. 他の試験においても 2 種類以上の温度設定を用 い,さらに湿潤・乾燥両状態を調べることにより，信頼 性の確認を行った。 また，比較のため一部は有限要素法 あるいはコントロールボリューム法による温度解析を行 い，試験結果との整合性を調べた。これらの試験には， 高価な装置や器具を用いずに, よ゙こでも行える簡便な方 法によったことも特徴の1つである.

\section{2. 配合および供試体}

表一1には，今回の試験に用いたコンクリートの配合， およびこれまでに著者らが主として熱伝導率の試験を 行ったコンクリートの配合を示す．また，表一2には， 熱伝導率の試験値および熱伝導率に影響があると思われ るデータをまとめた。ここで， $A / \rho$ は，単位コンクリー 卜質量に占める骨材の質量であり，マスコンクリートを 想定した西沢の実験では, $A / \rho=0.85$ が採用されてい る $^{15)}$.

表一3には，今回の試験に用いた供試体に関するデー 夕がまとめてある.ここで，湿潤状態とは28日間標準 養生した後水中からら取り出したまま，あるいは表面を拭 いた状態であり，乾燥状態とは $105^{\circ} \mathrm{C}$ の炬で表中の日 数乾燥したまま，あるいはそれに防水塗装サンユコート L-225を施した状態である. 平板比較法以外は, 供試 体を水中に浸すため乾燥状態の試験には向かないが，こ こでは防水塗装を施して試験し，後に塗装の影響を除去 する方法を採った。

\section{3. 試験方法}

\section{（1）平板比較法による熱伝導率試験}

供試体は $20 \mathrm{~cm} \times 20 \mathrm{~cm}$ の平板で, 厚さによる差を調 ベるため $3 \mathrm{~cm}$ 厚および $5 \mathrm{~cm}$ 厚の 2 種類をそれぞれ 3 枚使用した。試験は JIS A 1412 に準拠しており，図一1 に示すように側面を発泡スチロールで断熱して，高熱源 から低熱源へ一次元の定常熱流状態を実現するものであ る. 熱伝導率 $\lambda_{0}$ が既知である標準板（シリコンゴム製, 建材試験センターで検定済み）の温度差 $T_{2}-T_{1}$ と，供 試体の温度差 $T_{3}-T_{2}$ およびそれぞれの厚さ $d_{0}, d$ とか ら, 供試体の熱伝導率 $\lambda$ は,

$$
\lambda=\lambda_{0} \cdot \frac{d}{d_{0}} \cdot \frac{T_{2}-T_{1}}{T_{3}-T_{2}}
$$

により求まる. 熱電対は $\phi 0.2 \mathrm{~mm}$ の銅・コンスタンタ ン線であり，アルミテープにより標準板および供試体の 表面にはりつけた。高熱源側は, センシティブリレー SR-41に接続したパイプヒーターにより一定の温度に 保つことができ, 低熱源側は冷却機 NEOCOOL DIP BD-31 とパイプヒーターにより温度調節し，ラボポン プにより摜はんした.

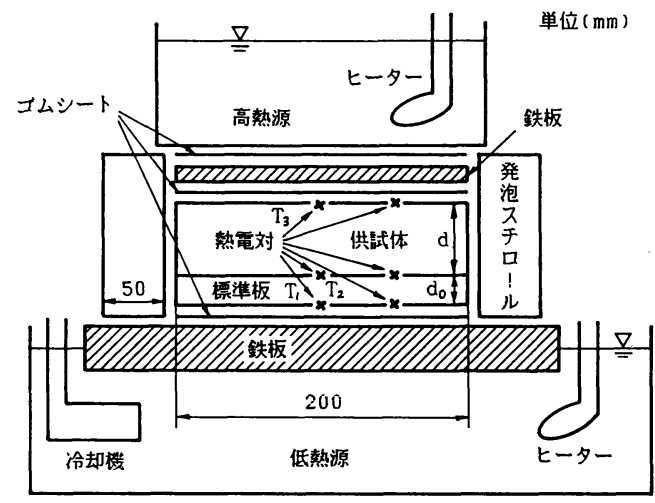

図一1 平板比較法の試験装置

表一1試験に用いたコンクリートの眍合

\begin{tabular}{|c|c|c|c|c|c|c|c|c|c|}
\hline & \multirow{2}{*}{$\begin{array}{c}\text { 盎骨材の } \\
\text { 最大寸法 } \\
(\mathrm{mm})\end{array}$} & \multirow{2}{*}{$\begin{array}{l}\text { スランブ } \\
(\mathrm{cm})\end{array}$} & \multirow{2}{*}{$\begin{array}{c}\text { 水セメント比 } \\
W / C \\
(\%)\end{array}$} & \multirow{2}{*}{$\begin{array}{l}\text { 細骨材事 } \\
\text { S/A } \\
(\%)\end{array}$} & \multicolumn{5}{|c|}{ 单位量 $\left(\mathrm{kg} / \mathrm{m}^{3}\right)$} \\
\hline & & & & & $\begin{array}{c}\text { セメント } \\
\mathrm{C} \\
\end{array}$ & $\begin{array}{l}\text { 水 } \\
W\end{array}$ & $\begin{array}{c}\text { 耕骨材 } \\
\mathrm{S}\end{array}$ & $\begin{array}{c}\text { 柤骨材 } \\
\text { G }\end{array}$ & 混和剂 \\
\hline 今回の試龭 & 20 & 10 & 42.0 & 41.0 & 417 & 173 & 681 & 1041 & $0.824\left(ハ^{\circ} リ ッ ク ）\right.$ \\
\hline 熱水タンク & 20 & 9 & 43.0 & 42.0 & 365 & 157 & 734 & 1106 & $1.46\left(n^{\bullet}\right.$ リック SS $)$ \\
\hline 摸型水槽 & 20 & 10 & 42.0 & 41.0 & 417 & 173 & 681 & 1041 & $0.824\left(n^{\bullet}\right.$ リック S) \\
\hline 天童タンク & 20 & 10 & 41.0 & 41.5 & 474 & 194 & 650 & 930 & $1.185\left(ハ^{\circ}\right.$ リック SS $)$ \\
\hline 能岡タンク & 25 & 8 & 37.2 & 35.3 & 400 & 149 & 614 & 1150 & 1.60 (プラストクリート) \\
\hline
\end{tabular}

表一2 熱伝道率および関連データ

\begin{tabular}{|c|c|c|c|c|c|c|c|c|c|c|}
\hline & \multirow{2}{*}{$\begin{array}{l}\text { 慜伝索案 } \\
\left(W \cdot m^{-1} \cdot K^{-1}\right)\end{array}$} & \multirow{2}{*}{$\begin{array}{l}\text { 厚さ } \\
(\mathrm{cm})\end{array}$} & \multicolumn{3}{|c|}{ 租骨材 } & \multicolumn{2}{|c|}{ 耕骨材 } & \multirow[t]{2}{*}{ 粮固め } & \multirow[t]{2}{*}{$\mathrm{A} / \rho$} & \multirow{2}{*}{ 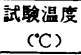 } \\
\hline & & & \multicolumn{2}{|c|}{ 岩種·産地 } & 吸水状息 & 種類 & 産地 & & & \\
\hline 今回の試駼 & 1.58 & 3,5 & 安山岩 & 名取市高啥 & 6時间吸水 & 川砂 & 白石川 & 突菶·木つち & 0.74 & 25 \\
\hline 熱水タンク & 1. 17 & 3,5 & 安山岩 & 江刺市伊手 & 24 時间吸水 & 川砂 & 玉川 & 突棒·木つち & 0.78 & 45 \\
\hline 模型水槽 & 1.00 & 2. 5 & 安山岩 & 名取市高舘 & 7日间吸水 & 川砂 & 白石川 & テーブルバイブレータ & 0.74 & 45 \\
\hline 天童タンク & 0.78 & 2.5 & 安山岩 碎石 身 & 東根市覾音寺 & しはしば散水 & 川砂 & 羽黑 & 木つち & 0.70 & 43 \\
\hline 部岡タンク & 0.94 & 3 & 花岡岩·安山岩 玉砛 & 砕 赤川水系 & 直前水洗 & 陸砂 & 赤川水秃 & 突棒·木つち & 0.76 & 42 \\
\hline
\end{tabular}


表一3 供試体に関するデータ

\begin{tabular}{|c|c|c|c|c|c|}
\hline & \multicolumn{3}{|c|}{ 熱伝導案 } & \multirow{2}{*}{$\begin{array}{c}\text { 比熱 } \\
\text { 混合法 }\end{array}$} & \multirow{2}{*}{$\begin{array}{c}\text { 熱拡散害 } \\
\text { Glover法 }\end{array}$} \\
\hline & & $\begin{array}{l}\text { 七教法 } \\
\text { A } 1412\end{array}$ & $\begin{array}{c}\text { 円筒直接法 } \\
\text { Niven法 }\end{array}$ & & \\
\hline 形状 & \multicolumn{2}{|c|}{ 平板 } & 円筒 & 巴柱 & 円柱 \\
\hline 寸法 $(\mathrm{cm})$ & $\begin{array}{c}20 \times 20 \\
\text { 厚さ5 }\end{array}$ & $\begin{array}{l}20 \times 20 \\
\text { 厚さ3 }\end{array}$ & $\begin{array}{l}\text { 外径24 内径11.4 } \\
\text { 高さ30 }\end{array}$ & 径5.5 高さ5.5 & 径10 高さ 20 \\
\hline $\begin{array}{l}\text { 固数 } \\
\text { 涂㳖 }\end{array}$ & $\begin{array}{l}3 \\
\text { 無 } \\
\end{array}$ & $\begin{array}{r}3 \\
\text { 無 } \\
\end{array}$ & $\begin{array}{l}1 \\
\text { 有 } \\
\end{array}$ & $\begin{array}{r}3 \\
\text { 有 } \\
\end{array}$ & $\begin{array}{l}2 \\
\text { 有 }\end{array}$ \\
\hline $\begin{array}{l}\text { 䡎燥日数 } \\
\text { 筫量娍 }(\%)\end{array}$ & $\begin{array}{r}4 \text { 日日 } \\
7.2\end{array}$ & $\begin{array}{l}3 \text { 日 } \\
7.5\end{array}$ & $\begin{array}{r}21 \text { 日 } \\
6.5\end{array}$ & $\begin{array}{l}\text { 3日 } \\
7.1\end{array}$ & $\begin{array}{r}7 \text { 日 } \\
7.7\end{array}$ \\
\hline
\end{tabular}

温度設定は 2 種類で，（I ）は $T_{3}$ を気温より $7^{\circ} \mathrm{C}$ 程 度高く $T_{1}$ を気温より $7^{\circ} \mathrm{C}$ 程度低く，（II）は $T_{3}$ を気温 より $20^{\circ} \mathrm{C}$ 程度高くし, 低熱源側鉄板を直接空気にさら す簡便な方法とした，定常状態に達するまでの時間は供 試体の厚さにもよるが, 設定温度（I）では $2 \sim 3$ 時間, 設定温度（II）では $3 \sim 4.5$ 時間であった.

（2）円筒直接法による熱伝真率試験

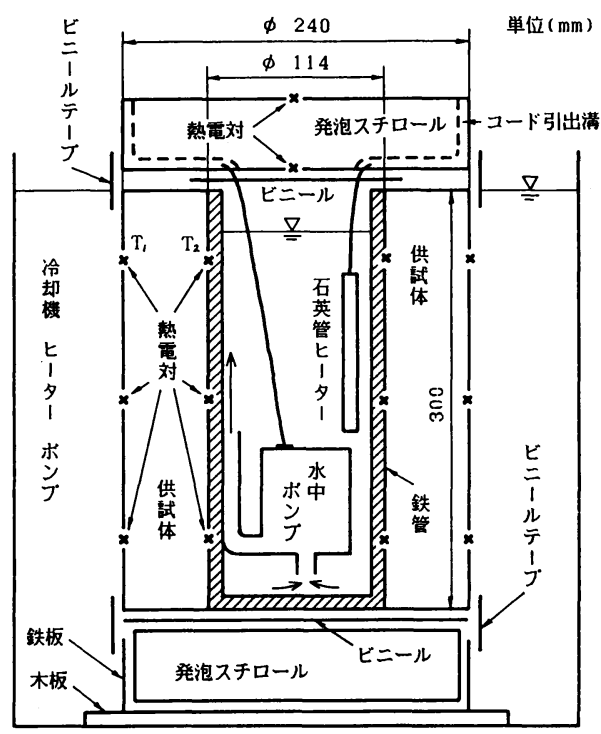

図一2 円筒直接法の試硢装置
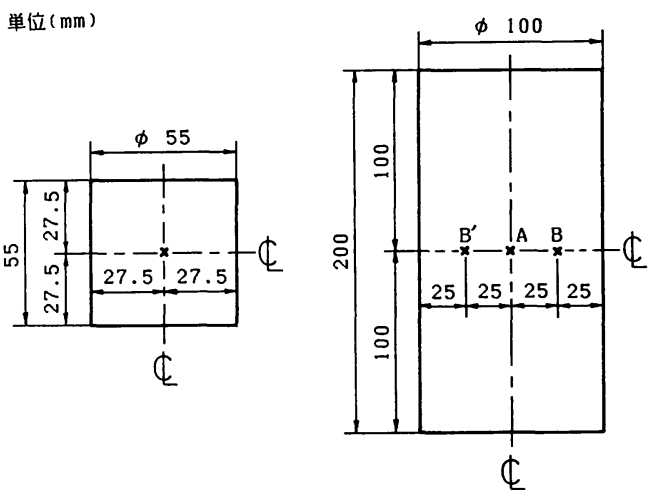

（1）比熱試験

（2）熱拡散率試験

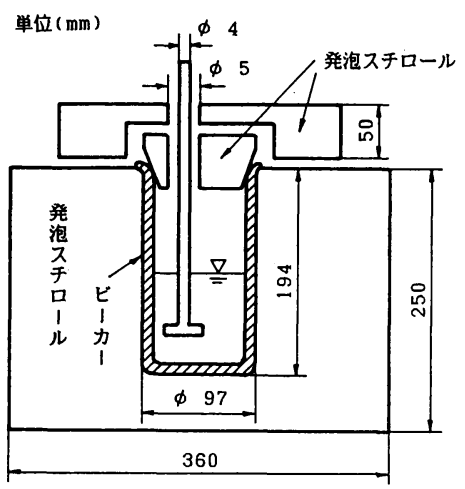

図一4 比熱試験用熱贵計

試験法による差を調べるために, Niven 法 ${ }^{16), 17)}$ に準じ た円筒直接法による試験も行った. 供試体は高さ $30 \mathrm{~cm}$, 内径 $11.4 \mathrm{~cm}$, 外径 $24 \mathrm{~cm}$ の円筒であり, 内側に $4 \mathrm{~mm}$ 厚の鉄管を埋め込んだ.

試験は, 図一2のように外側の水を冷却機およびヒ一 ターで一定に保ちながらラボポンプにより摜はんし，内 側の水を石英管ヒーターで加熱して水中ポンプ MDS-10 Nにより䚓はんし，定常状態を実現するもの である. 内外の水温が高さ方向に変化しないかどうかを 調べるため, $\phi 0.32 \mathrm{~mm}$ の熱電対を 3 か所に取り付け たが，結果としてまったく温度差が認められなかった。

上下の温度差がなく放射状の定常熱流状態となったと き, 内部の発熱による熱流 $Q$ が知られれば,

$$
\lambda=\frac{Q \cdot \ln \left(r_{1} / r_{2}\right)}{2 \pi l\left(T_{2}-T_{1}\right)}
$$

により熱伝導率が求められる.ここで， $r_{1}, r_{2}$ は供試 体の外半径, 内半径, $l$ は供試体の高さ, $T_{2}, T_{1}$ は内面, 外面の温度である.なお，熱電対の取り付けは，内側に ついては鉄管にアルミテープではりつけたままコンク リートを打設し, 外側については脱型後 $2 \mathrm{~mm}$ 程度の溝 を切って熱電対をはわせ, 感温部が表面にくるようにセ メントペーストで埋め込んだ.

内部からの熱流は，スライダックにより石英管ヒ一 夕一への付加電圧 $E_{v}$ を $45 \mathrm{~V}, 38 \mathrm{~V}, 25 \mathrm{~V}, 0 \mathrm{~V}$ (水中 ポンプの発熱および摫はんのみによる状態）に変えるこ

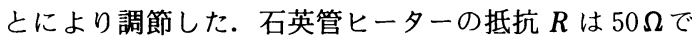
あり，付加電圧が定まれば

$$
Q=\frac{E_{v}^{2}}{R} \text {. }
$$

から熱流が求められる.

\section{（3）比熱試験}

比熱は，混合法 ${ }^{17)}$ または断熱カロリーメーター法18)に より直接測定するか, 熱伝導率と熱拡散率 $h^{2}$ を測定し, 密度 $\rho$ を用いて 


$$
C=\frac{\lambda}{h^{2} \rho}
$$

により計算することができる.ここでは， $\lambda, C, h^{2}, \rho$ を独立に測定して式（4）により結果の妥当性を確認す るのが目的なので，装置の簡便な混合法によった。

供試体は, 直径 $55 \mathrm{~mm}$, 高さ $55 \mathrm{~mm}$ の円柱 3 個とし, 図一3のように中心部に熱電対を埋め込んだ。試験の概 要は, 最初温度 $T_{3}$ の水中に質量 $M$ の供試体を温度が 一致するまで浸し，次に熱量計（図一4に示すように発 泡スチロールで断熱した容器）の温度 $T_{1}$, 質量 $W$ の水 中に移し, 両者の温度が一致する $T_{2}$ を調べるものであ る. 比熱は,

$$
C=\frac{\left(W+W_{0}\right)\left(T_{2}-T_{1}\right)}{M\left(T_{3}-T_{2}\right)}
$$

から求められる. ここで, 熱量計の水当量 $W_{0}$ は, 供試 体とほぼ同体積の水 $W_{1}$ で同一の試験を行うことによ り,

$$
W_{0}=\frac{W_{1}\left(T_{3}-T_{2}\right)}{T_{2}-T_{1}}-W
$$

で求められる．温度設定は 2 種類で，（I）が $T_{3}$ を気 温より約 $20^{\circ} \mathrm{C}$ 高く $T_{1}$ を気温より約 $7^{\circ} \mathrm{C}$ 低くし， (II) が $T_{3}$ を気温より約 $20^{\circ} \mathrm{C}$ 低く $T_{1}$ を気温より約 $7^{\circ} \mathrm{C}$ 高く した。供試体が周囲の水温と一致するまでに, 乾燥状態 · 湿潤状態ともに 15 分程度かかっているが， $T_{1}, T_{2}$ とも に気温と大差がないため，それらの時間的な変動が十分 小さいことも確認してある.

\section{（4）熱拡散率の試験}

Glover $の$ 方法 ${ }^{15)}$ に従い, 直径 $10 \mathrm{~cm}$, 高さ $20 \mathrm{~cm}$ で, 図一3のように中心および直径の 4 等分点に熱電対を埋

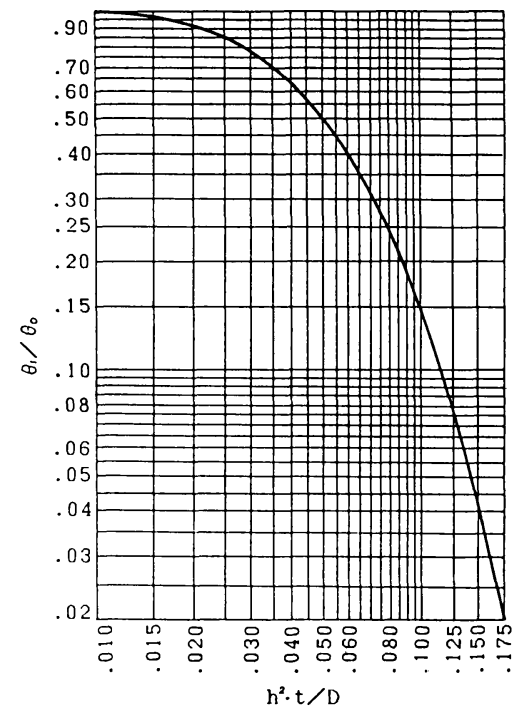

図一5 中心温度と熱拡散率の関係
め込んだ供試体 2 個を用いた。高温槽と低温槽の温度差 を約 $20^{\circ} \mathrm{C}$ とし，高温槽はヒーターのみで，低温槽は冷 却機とヒーターで温度調節し，いずれもラボポンプで摜 はんした。

高温槽で中心まで一様な温度 $T_{3}$ となった供試体を低 温槽に移し, 中心温度 $T_{2}$ と水温 $T_{1}$ の差および時刻の関 係から，図一5のグラフにより熱拡散率を求めることが できる.ここで, $\theta_{0}=T_{3}-T_{1}, \theta_{1}=T_{2}-T_{1}, t$ は時間, $D$ は供試体の直径である．この試験では，低温槽で一 様な温度になった供試体を再び高温槽に移し，温度分布 が逆になる状態での試験も行った。

\section{4. 試験結果}

\section{（1）平板比較法}

表一4に結果を示すが, 乾湿の違い, 設定温度の違い, 厚さの違い，供試体の違いに対し，それぞれに差が認め られる. 湿潤状態の試験値に対する乾燥状態の試験值の 比率は, $0.71 \sim 0.81$ の範囲にあり平均で 0.77 である. 設定温度 (I ) での試験値に対する設定温度（II）での 試験値の比率は, 乾湿両状態で $0.87 \sim 0.98$ の範囲にあ

\begin{tabular}{|c|c|c|c|c|c|c|}
\hline \multirow[t]{2}{*}{ 厚さ } & \multirow[t]{2}{*}{ 乾・湿 } & \multirow[t]{2}{*}{ 設定温度 } & \multicolumn{3}{|c|}{ 供栻体 } & \multirow[t]{2}{*}{ 平均 } \\
\hline & & & 1 & 2 & 3 & \\
\hline \multirow{4}{*}{$5 \mathrm{~cm}$} & 湿洞 & I & 1.41 & 1.38 & 1.31 & 1.37 \\
\hline & & $\Pi$ & 1.15 & 1.28 & 1.14 & 1.19 \\
\hline & 䡎燥 & I & 1.01 & 0.96 & 0.97 & 0.98 \\
\hline & & $\Pi$ & 0.99 & 0.94 & 0.95 & 0.96 \\
\hline \multirow{4}{*}{$3 \mathrm{~cm}$} & 湿洞 & I & 1.14 & 1.18 & 1.23 & 1.18 \\
\hline & & $\Pi$ & 1.09 & 1.16 & 1.01 & 1.09 \\
\hline & 乾㷘 & $I$ & 0.89 & 0.93 & 0.91 & 0.91 \\
\hline & & $\Pi$ & 0.84 & 0.81 & 0.86 & 0.84 \\
\hline
\end{tabular}
り平均で 0.92 である.

表一4 平板比較法による熱伝草率 (単位 $: \mathrm{W} \cdot \mathrm{m}^{-1} \cdot \mathrm{K}^{-1}$ )

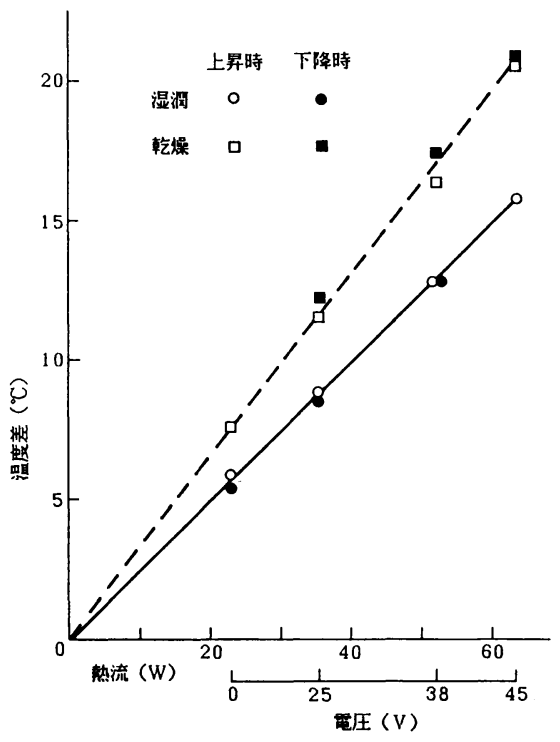

図一 熱流と温度差の関係 
厚さによる試験値の差は, $5 \mathrm{~cm}$ 厚に対する $3 \mathrm{~cm}$ 厚の 比として表わしたが, 乾湿および設定温度の違いによる 差は認められず, $0.87 \sim 0.93$ の範囲でその平均は 0.90 である.

\section{（2） 円筒直接法}

式（3）で計算される熱流と測定された内外温度差と は直線関係になるが，この直線を延長し温度差がゼロの 線との交点を原点とすれば, 水中ポンプによる発熱を加 えた熱流に対するグラフとなる（図一6）。ただし，温度 差と熱流とが比例関係にあるので, 式（2）で熱伝導率 を算出する際には水中ポンプによる熱流の影響はない. また図一6で，上昇時，下降時とは付加電圧を順次上げ ていくまたは下げていく過程のことで, 電圧を一定にし てから定常状態に達するまでに約 4 時間を要した.

この試験では, 内部の発熱量のうち供試体を通過する 熱の割合を正確に知る必要がある. 図一2にも示したよ うに, ヒーターは完全に水中に没しており，ヒーターお よびポンプの電源コードは, 上部の発泡スチロール板に 溝を切って引き出しているため, 熱の損失はきわめて少 ないものと考えられる.また, 別に測定した発泡スチロー ルの熱伝導率 $0.042 \mathrm{~W} \cdot \mathrm{m}^{-1} \cdot \mathrm{K}^{-1}\left(0.036 \mathrm{kcal} \cdot \mathrm{m}^{-1} \cdot \mathrm{h}^{-1}\right.$. $\left.{ }^{\circ} \mathrm{C}^{-1}\right)$ を用い, 上下の断熱部からの損失熱量を算出した が, 最も比率の大きいヒーター停止時でも $0.3 \%$ に過 ぎなかった. 図一6に示した直線の勾配から熱伝導率を 算出すると, 湿潤状態では $1.58 \mathrm{~W} \cdot \mathrm{m}^{-1} \cdot \mathrm{K}^{-1}(1.36 \mathrm{kcal} \cdot$ $\left.\mathrm{m}^{-1} \cdot \mathrm{h}^{-1} \cdot{ }^{\circ} \mathrm{C}^{-1}\right)$, 乾燥状態で $1.13 \mathrm{~W} \cdot \mathrm{m}^{-1} \cdot \mathrm{K}^{-1}(0.98 \mathrm{kcal} \cdot$ $\left.\mathrm{m}^{-1} \cdot \mathrm{h}^{-1} \cdot{ }^{\circ} \mathrm{C}^{-1}\right)$ となった.

\section{（3）比熱}

表一 5 に, 水当量を求めた試験結果を示すが, 設定温 度によって値が異なること, 3 回の試験に対して結果が 大きくばらついていることがわかる. 設定温度を気温に 対してほぼ対称に定めているにもかかわらず, 異なる值 が得られているが, その理由は定かではない.ちなみに, ビーカーの質量およびガラスの比熱により算出した水当 量は $53 \mathrm{~g}$ である. 水当量の試験結果が大きくばらつく ことは, 式 (6) が温度差の比で水量 $W_{1}$ を拡大し, さ らに水量 $W$ を差し引く形になっているためである。 た だし, 水当量で $10 \mathrm{~g}$ の誤差は式（5）では, 最も条件 の悪い設定温度（II）でも，比熱に対しては $2.7 \%$ の 誤差となるに過ぎないので, 問題はないと思われる.

供試体についての試験結果を表一6に示す．乾燥供試 体については, 同じ試験で求めた塗装の比熱 $C^{\prime}=1.41$ $\mathrm{kJ} \cdot \mathrm{kg}^{-1} \cdot \mathrm{K}^{-1}\left(0.34 \mathrm{kcal} \cdot \mathrm{kg}^{-1} \cdot{ }^{\circ} \mathrm{C}^{-1}\right)$ と質量 $M^{\prime}$ から, 補正量 $\Delta C$ は

$$
\Delta C=\frac{C^{\prime} M^{\prime}}{M}
$$

により計算されるがその割合は $2 \%$ 程度であった．以

\begin{tabular}{c|c|c|c|c}
\multicolumn{5}{c}{ 表 -5 水当目 (単位 $: g$ ) } \\
\cline { 1 - 4 } & \multicolumn{3}{c}{ 平均 } \\
\cline { 2 - 4 } & 1 & 2 & 3 & \\
\hline $\mathrm{I}$ & 45 & 52 & 59 & 52 \\
$\mathrm{I}$ & 14 & 13 & 25 & 17 \\
\hline
\end{tabular}

\begin{tabular}{|c|c|c|c|c|c|}
\hline \multirow{2}{*}{ 乾・湿 } & \multirow[t]{2}{*}{ 段定温度 } & \multicolumn{3}{|c|}{ 基試体 } & \multirow[t]{2}{*}{ 平均 } \\
\hline & & 1 & 2 & 3 & \\
\hline \multirow[t]{2}{*}{ 湿酒 } & $I$ & 1.04 & 1.03 & 1.10 & 1.06 \\
\hline & $\Pi$ & 0.99 & 1.06 & 1.05 & 1.03 \\
\hline \multirow[t]{2}{*}{ 䡎燥 } & I & 0.82 & 0.87 & 0.86 & 0.85 \\
\hline & $\Pi$ & 0.89 & 0.79 & 0.91 & 0.86 \\
\hline
\end{tabular}

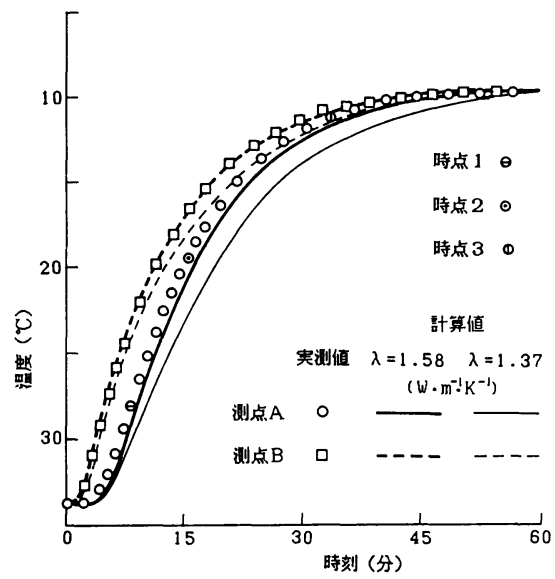

図一7 測点の温度变化（湿潤状態）

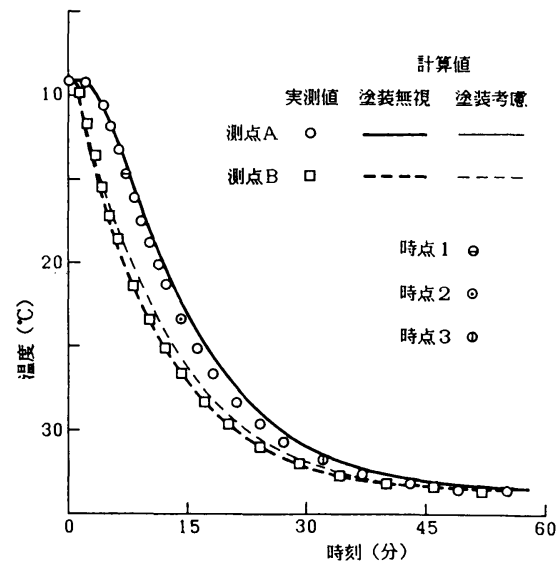

図一8 測点の温度变化（乾燥状態）

上の結果から，供試体 3 個および設定温度 2 種に対する 平均をとると, 湿潤状態の比熱が $1.05 \mathrm{~kJ} \cdot \mathrm{kg}^{-1} \cdot \mathrm{K}^{-1}$ $\left(0.25 \mathrm{kcal} \cdot \mathrm{kg}^{-1} \cdot{ }^{\circ} \mathrm{C}^{-1}\right)$, 乾燥状態の比熱が $0.86 \mathrm{~kJ}$. $\mathrm{kg}^{-1} \cdot \mathrm{K}^{-1}\left(0.20 \mathrm{kcal} \cdot \mathrm{kg}^{-1} \cdot{ }^{\circ} \mathrm{C}^{-1}\right)$ となる.

\section{（4）熱 拡散率}

図一7，8には，湿潤状態で供試体（1）の高温から 低温への試験, 乾燥状態で供試体（2）の低温から高温 への試験における, 各測点温度の時間的変化を示した. 
表一7 熱拡散率 (単位: $\times 10^{-3} \mathrm{~m}^{2} / \mathrm{h}$ )

\begin{tabular}{|c|c|c|c|c|c|c|}
\hline \multirow[t]{2}{*}{ 䡎・湿 } & \multirow[t]{2}{*}{ 供試体 } & \multirow[t]{2}{*}{ 設定温度 } & \multicolumn{3}{|c|}{ 時点 } & \multirow[t]{2}{*}{ 平均 } \\
\hline & & & 1 & 2 & 3 & \\
\hline \multirow{4}{*}{ 湿洞 } & 1 & I & 2.33 & 2.40 & 2.36 & \multirow{4}{*}{2.30} \\
\hline & & $\Pi$ & 2.10 & 2.23 & 2.22 & \\
\hline & 2 & I & 2.30 & 2.35 & 2.37 & \\
\hline & & $\Pi$ & 2.30 & 2.30 & 2.29 & \\
\hline \multirow{4}{*}{ 乾燥 } & 1 & I & 2.25 & 2.35 & 2.24 & \multirow{4}{*}{2.31} \\
\hline & & $\Pi$ & 2.31 & 2.31 & 2.34 & \\
\hline & 2 & I & 2.30 & 2.38 & 2.38 & \\
\hline & & $\Pi$ & 2.22 & 2.31 & 2.31 & \\
\hline
\end{tabular}

これから, 供試体の中心が周囲の水温と一致するまでに, 45 分を費やしているのがわかる．また，図中の計算値 については次章で述べる.

全試験について, それぞれ時刻と温度 3 点を拾い熱拡 散率を算出した結果を表一7に示す，湿潤状態と乾燥状 態で有意な差が認められず,平均がそれぞれ $2.30 \times 10^{-3}$ $\mathrm{m}^{2} / \mathrm{h}$ および $2.31 \times 10^{-3} \mathrm{~m}^{2} / \mathrm{h}$ であること，またグラフ から読み取った值を用いているにもかかわらず，ばらつ きの少ない結果が得られていることがわかる.

\section{5. 試験結果の検討}

平板比較法において供試体厚の違いにより，熱伝導率 に $10 \%$ 程度の差が出ているが, 熱水タンクの場合にも 同様に $17 \%$ 程度の差がみられた，厚さにより熱伝導率 の試験值に差が出る理由の 1 つとして, 熱電対が置かれ た面での接触熱抵抗が考えられる19).この試験で用いる 熱電対は $\phi 0.2 \mathrm{~mm}$ であり, 標準板がゴム製であること, 供試体上の鉄板および高熱源水槽の総質量が $12 \mathrm{~kg}$ に達 することを考えれば，それぞれの面の密着度はかなりよ いと思われる. しかしながら，コンクリートのような粗 面の材質では，接触熱抵抗が無視できないと思われ，そ の影響は供試体が薄いほど相対的に大きいと考えられ る.また，温度設定では気温との差が小さい（Ｉ）の方 がよりよい精度が期待できると思われるので, 以下平板 比較法の試験值としては， $5 \mathrm{~cm}$ 厚・設定温度（I）の 值を用いる.

熱伝導率, 比熱, 熱拡散率の間には式 (4) の関係が あるため,これら 3 量を独立に試験した場合には, 精度 の確認を行うことができる. 湿潤状態について, 平板比 較法の $5 \mathrm{~cm}$ 厚供試体から得られた熱伝導率で計算した 熱拡散率は $1.98 \times 10^{-3} \mathrm{~m}^{2} / \mathrm{h}$ であり実測值 $2.30 \times 10^{-3}$ $\mathrm{m}^{2} / \mathrm{h}$ に対し $13.9 \%$ の誤差, 円筒直接法から得られた 值で計算した結果は $2.28 \times 10^{-3} \mathrm{~m}^{2} / \mathrm{h}$ で $1 \%$ の誤差とな る. 乾燥状態については, 平板比較法による試験値で算 出した值は $1.87 \times 10^{-3} \mathrm{~m}^{2} / \mathrm{h}$ となり誤差は $18.7 \%$, 円 筒直接法では $2.16 \times 10^{-3} \mathrm{~m}^{2} / \mathrm{h}$ で $6.1 \%$ の誤差である. したがって, 円筒直接法が平板比較法よりも精度がよい ことがわかる.

図一7,8の実線および破線は, 平板比較法で得られ
た熱伝導率 $1.37 \mathrm{~W} \cdot \mathrm{m}^{-1} \cdot \mathrm{K}^{-1}\left(1.18 \mathrm{kcal} \cdot \mathrm{m}^{-1} \cdot \mathrm{h}^{-1} \cdot{ }^{\circ} \mathrm{C}^{-1}\right)$ および円筒直接法による $1.58 \mathrm{~W} \cdot \mathrm{m}^{-1} \cdot \mathrm{K}^{-1}(1.36 \mathrm{kcal}$. $\left.\mathrm{m}^{-1} \cdot \mathrm{h}^{-1} \cdot{ }^{\circ} \mathrm{C}^{-1}\right)$, 密度 $2380 \mathrm{~kg} / \mathrm{m}^{3}$ および比熱 $1.05 \mathrm{~kJ}$. $\mathrm{kg}^{-1} \cdot \mathrm{K}^{-1}\left(0.25 \mathrm{kcal} \cdot \mathrm{kg}^{-1} \cdot{ }^{\circ} \mathrm{C}^{-1}\right)$ を用い，図一9に示し

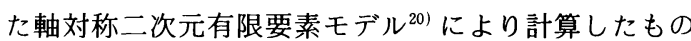
である.たとえば，図一7の場合周辺は $9.6^{\circ} \mathrm{C}$ の一定温 度境界, 内部点をすべて $33.8^{\circ} \mathrm{C}$ の初期条件で解く非定 常熱伝導問題とし，時間積分は完全陰解法，時間きざみ を 1 分とした. 計算値は, 中心部 (測点 $A$ ), 1/4 等分 点部 (测点 B) ともよく测定值と一致しており，ここ でも円筒直接法による熱伝導率がよりよい結果を与えて いる.ここで測点 B の試験值は, 図一3における測点 $\mathrm{B}$, $\mathrm{B}^{\prime}$ の平均値である.

図一8の計算値は, 図一9 の計算モデルで熱物性值だ けを乾燥状態に変えたもの (塗装無視), および外側に $0.5 \mathrm{~mm}$ 厚の塗装部分を追加したもの（塗装考慮）によ り求めた. 結果は, 塗装を考虑するかしないかで大差は なく, 特に中心では図に現われるほどの差が認められな いため実線は 1 本となっており，いずれの曲線も実測 データに近い值を示している.この結果から, 熱拡散率 の試験においても, 塗装の影響は無視し得る程度である ことがわかる.ちなみに, 熱伝導率試験用の円筒供試体 では, 熱電対が塗装の内側にあるため, 塗装の影響はまっ たくなく, 結局最も小さい供試体である比熱試験におけ る $2 \%$ の影響が最大であったことになる.

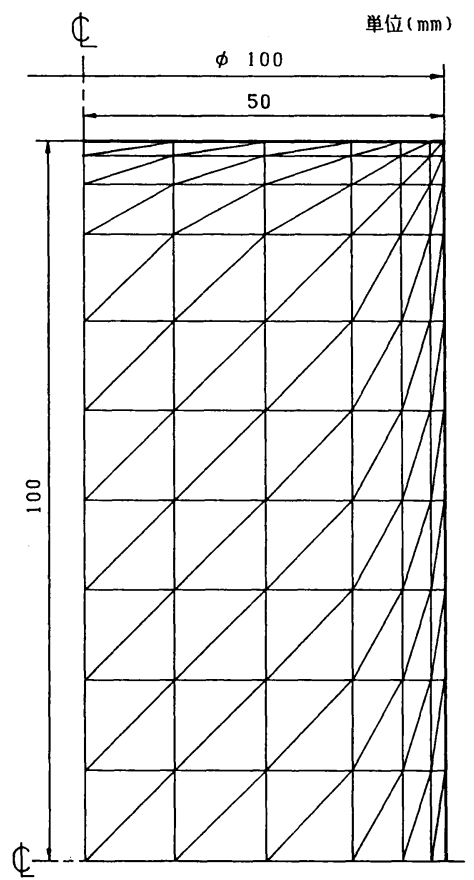

図一9計算モデル（熱拡散） 
円筒直接法の熱伝導率を用いて, 湿潤状態に対する乾 燥状態の比率を求めると 0.68 となる.これは, Campbell $^{21)}$ および阿部ら ${ }^{22)}$ の 0.65 と, 古村 ${ }^{23)} の 0.71$, 文献 5$)$ の 0.79 の中間的な値となっている.

今回円筒直接法で得られた熱伝導率 $1.58 \mathrm{~W} \cdot \mathrm{m}^{-1} \cdot \mathrm{K}^{-1}$ $\left(1.36 \mathrm{kcal} \cdot \mathrm{m}^{-1} \cdot \mathrm{h}^{-1} \cdot{ }^{\circ} \mathrm{C}^{-1}\right)$ は, 文献にみられる值に比 ベるとかなり小さいが, 徳田らの実験式 ${ }^{13)}$ から容易に推 定できる範囲である．徳田らの実験式

$$
\lambda=a+b\left(\frac{A}{\rho}\right)^{2}
$$

で $a$ および $b$ は実験から定まる定数であるが， $A / \rho=0$ のときセメントペーストの熱伝導率に一致するように $a$ $=1.28 \mathrm{~W} \cdot \mathrm{m}^{-1} \cdot \mathrm{K}^{-1}\left(1.10 \mathrm{kcal} \cdot \mathrm{m}^{-1} \cdot \mathrm{h}^{-1} \cdot{ }^{\circ} \mathrm{C}^{-1}\right), A / \rho=$ 1 のとき安山岩の熱伝導率 ${ }^{24}$ に一致するように $a+b=$ $0.98 \sim 1.76 \mathrm{~W} \cdot \mathrm{m}^{-1} \cdot \mathrm{K}^{-1}\left(0.85 \sim 1.51 \mathrm{kcal} \cdot \mathrm{m}^{-1} \cdot \mathrm{h}^{-1} \cdot{ }^{\circ} \mathrm{C}^{-1}\right)$ と決めることができる. もちろん,これでは粗骨材と細 骨材の熱伝導率の差を無視したことになるが, 実験によ らず簡便に推定するための第一近似である.ここで, $A / \rho=0.7$ とすると, $1.13 \sim 1.53 \mathrm{~W} \cdot \mathrm{m}^{-1} \cdot \mathrm{K}^{-1}(0.98 \sim$ $\left.1.32 \mathrm{kcal} \cdot \mathrm{m}^{-1} \cdot \mathrm{h}^{-1} \cdot{ }^{\circ} \mathrm{C}^{-1}\right)$ が得られる. すなわち, 安山 岩や玄武岩のように熱伝導率の低い骨材を使ったコンク リートの熱伝導率が低いことは当然なのである.

ただしここで用いた安山岩の熱伝導率は乾燥状態の 值であるため, 十分に吸水させた骨材を使用したコンク リートは, もっと高い熱伝導率を与える可能性がある. また，バイブレータで十分に締め固めた供試体では, 50 \% 程度高い值になるとのデータもあるが23), 今回の試 験からはそれを確かめることができない。しかし, 現場 で実際に使われているコンクリートの熱伝導率が，骨材 の吸水が十分でないためこれよりも低い值を与える可能 性があることに留意する必要がある.

\section{6. 平板比較法の適用性に関する検討}

JIS A 1412 平板比較法は, かなり均質で乾燥した供 試体のための試験法である，湿潤供試体では，熱の移動 之同時に水分の移動も生じるので, 測定誤差の原因とな ることが考えられる ${ }^{25)}$. しかし, 円筒直接法による試験 値と比較した結果, 湿潤・乾燥両状態でともに $13.5 \%$ 低い值が得られており, 水分移動の影響は現われていな い. むしろ, 供試体厚や設定温度により差が出ることが 重大であるが, 円筒直接法に比べ

（1）供試体の作成・試験の操作が簡単である

（2）塗装する必要がないため含水率を種々に変えた 試験を繰り返し行える

等の利点があるため, 適当な補正方法を確立すれば, コ ンクリートの有力な試験方法となる可能性がある.ちな みに, 今回の試験で得られた比率により,これまでの著
者らの試験值に対する補正率を計算してみると, 熱水夕 ンクで $20 \%$, 他は厚さの $2.5 \mathrm{~cm} と 3 \mathrm{~cm}$ の差を無視す ると $28 \%$ となる.

図一1において, 側面部を断熱しても若干の熱の流出 があるので, $T_{3}-T_{1}$ 間の温度差を $7^{\circ} \mathrm{C}$ 程度におさえる のがよいとの指摘もある ${ }^{26)}$. 一方で, 温度の読み取り誤 差を小さくするため, JIS では $T_{3}-T_{2}, T_{2}-T_{1}$ ともに $3{ }^{\circ} \mathrm{C}$ 以下にならないようにと規定している.一般には, この 2 条件を満足することは不可能なので, ここでは後 者を重視して $14^{\circ} \mathrm{C}$ 程度の温度差とした. ただし, 設定 温度（I）は気温を基準にして $T_{3}$ を $+7^{\circ} \mathrm{C} ， T_{1}$ を一 $7^{\circ} \mathrm{C}$ とたため, 良好な試験条件になっているものと考 えられる.

供試体の厚さについて, 棚沢は試験誤差を $1 \%$ 以内 におさめるためには, $d+d_{0}$ を供試体幅の $1 / 5$ 以下に する必要があると報告しており ${ }^{27)}$, JIS でも供試体厚を $2.5 \mathrm{~cm}$ 以下に規定している.ここでは供試体幅が 20 $\mathrm{cm}$ で標準板の厚さが $2 \mathrm{~cm}$ なので,これらの制限に従 うと供試体の厚さを $2 \mathrm{~cm}$ 以下にしなければならない. しかしながら, 最大骨材寸法が $25 \mathrm{~mm}$ のコンクリート では供試体の作成が不可能であり， $3 \mathrm{~cm}$ 厚まで許容し たとしても不均質な部分で測定してしまう可能性があ る. 棚沢の計算および JIS の規定は, 側面を断熱せず に空気にさらした場合について行ったものであり，断熱 により試験誤差が減少することは明らかである.

そこで，断熱による効果を調べるため，図一10の計 算モデルを用い三次元の定常熱伝導問題として, コント ロールボリューム法 ${ }^{28)} に よ り$ 温度分布の計算を行った. 図は供試体の厚さが $3 \mathrm{~cm}$ の場合であり, 右側は要素分 割を, 左側は温度境界条件を示している. 設定温度 (I ) に対しては, $T_{1}=13^{\circ} \mathrm{C}, T_{3}=27^{\circ} \mathrm{C}, T_{0}=20^{\circ} \mathrm{C}$ を, 設定 温度（II）に対しては, $T_{1}=25^{\circ} \mathrm{C}, T_{3}=39^{\circ} \mathrm{C}, T_{0}=$ $20^{\circ} \mathrm{C}$ の固定温度境界を用い, 熱伝導率は供試体が 1.58 $\mathrm{W} \cdot \mathrm{m}^{-1} \cdot \mathrm{K}^{-1}\left(1.36 \mathrm{kcal} \cdot \mathrm{m}^{-1} \cdot \mathrm{h}^{-1} \cdot{ }^{\circ} \mathrm{C}^{-1}\right)$, 標準板が $0.237 \mathrm{~W} \cdot \mathrm{m}^{-1} \cdot \mathrm{K}^{-1}\left(0.204 \mathrm{kcal} \cdot \mathrm{m}^{-1} \cdot \mathrm{h}^{-1} \cdot{ }^{\circ} \mathrm{C}^{-1}\right)$, 発泡ス

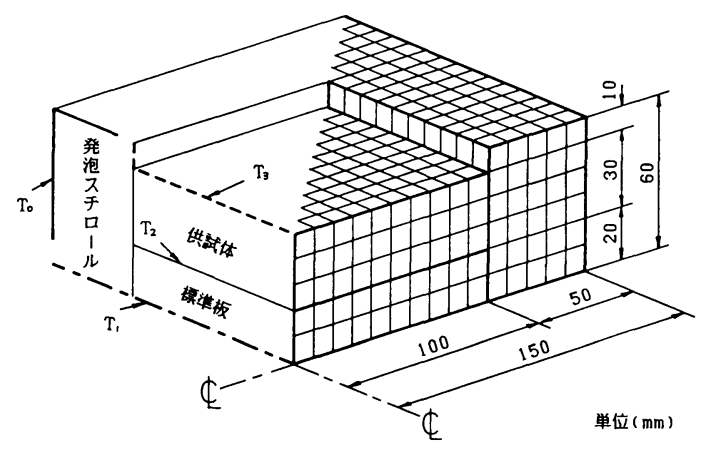

図一10 計篗モデル（熱伝導） 
チロールが $0.042 \mathrm{~W} \cdot \mathrm{m}^{-1} \cdot \mathrm{K}^{-1}\left(0.036 \mathrm{kcal} \cdot \mathrm{m}^{-1} \cdot \mathrm{h}^{-1}\right.$. $\left.{ }^{\circ} \mathrm{C}^{-1}\right)$ とした。 また, 棚沢の計算と比較するため, 断熱 材を取り去り, 下面の温度 $T_{1}$ と側面の温度を等しくし た計算も行った. 図一11および 12 は, 今回の試験（側 面断熱）および棚沢の計算（側面断熱せず）に対応した 結果を, 供試体厚 $5 \mathrm{~cm}$ に対して等温線で表わしたもの である，図一11では，供試体内の等温線がほとんど水 平であるが，図一12では中心の近傍まで等温線が傾い ていることがわかる．また，側面を断熱しない場合には 供試体の温度差が大きくなり，見掛け上小さな熱伝導率 が得られることもわかる.

表一8には，供試体の厚さを変化させたときの，与え られた熱伝導率に対する，計算された温度分布から得ら れる見掛け上の熱伝導率の誤差を示した。側面を断熱し ない場合には，厚さの増加とともに急激に誤差が増大す るが，断熱した場合には供試体厚さ $10 \mathrm{~cm}$ でもなお誤 差が $0.1 \%$ にすぎなく，側面断熱の効果は非常に大き いことがわかる．ただし，モデル計算上では設定温度 （I），（II）ともほとんど試験誤差が現われないにもか かわらず，胃実には（Ｉ），（II）で８％程度の差が出 ている．この原因は定かではないが，発泡スチロールと 供試体および鉄板間のすき間を接着しているわけではな いので,わずかではあるが空気が流れることが考えられ， 計算モデルについてさらに検討する余地がある。なお， 側面を断熱しない場合については, 棚沢の結果と直接比

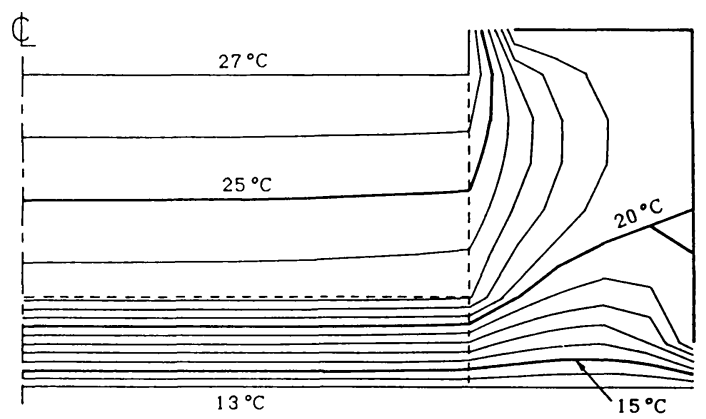

図一11 等温線（側面断熱）

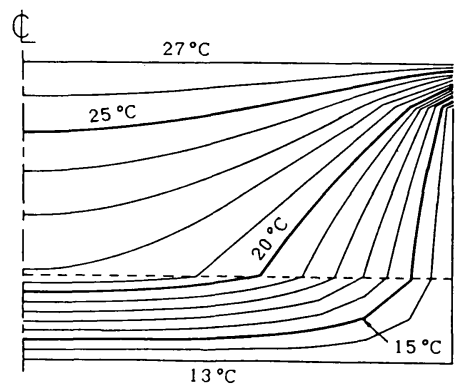

図一12 等温線（側面断熱せず）
表一8 厚さによる熱伝道來の誤差（単位：\%）

\begin{tabular}{|c|c|c|c|c|c|c|}
\hline \multicolumn{2}{|c|}{ 供試体厚さ $(\mathrm{cm})$} & 2 & 3 & 5 & 7 & 10 \\
\hline \multicolumn{2}{|c|}{ 侧面断熱せず } & 2.2 & 11.8 & 38.2 & 56.6 & 71.3 \\
\hline \multirow[t]{2}{*}{ 侧面断熱 } & 設定温度 I & - & - & - & - & 0.1 \\
\hline & 設定温度 & - & - & - & - & 0.1 \\
\hline
\end{tabular}

較するために，供試体の厚さと熱伝導率を標準板と同一 にした計算も行ったが，誤差は $0.6 \%$ で棚沢の $1 \%$ よ りも若干小さいだけであり, 計算の妥当性を裏づけてい る.

円筒直接法による結果との比較から，平板比較法では $5 \mathrm{~cm}$ 厚供試体が $3 \mathrm{~cm}$ 厚のものより精度がよいことが 知られた。 またモデル計算により，側面断熱の効果が大 きく，供試体厚を増すことで急激に試験誤差を増大させ ることもない,ことが推定される。したがって，JIS の 規定にもかかわらず，側面を断熱した場合には，供試体 厚を $5 \mathrm{~cm}$ 程度に増やすべきであると判断される．ただ し，供試体厚の限度あるいは試験値に対する補正率につ いては，さらに実験および計算によって調べる必要があ る. 特に，コンクリートの熱伝導率試験については, 実 験室による差が大きいことも報告されており ${ }^{29)}$, 組織的 な研究が望まれる.

\section{7. あとがき}

安山岩を骨材とするコンクリートの一配合について, 一連の熱物性試験を行った結果, 次のようなことが知ら れた。

（1）熱伝導率, 比熱, 熱拡散率を独立に試験し，3 者の満足すべき関係を調べたところ，誤差は $1 \%$ から $6.1 \%$ の範囲にあり，一応の精度が得られていることが 確認された。

（2）熱伝導率試験では円筒直接法が精度がよく, 湿 潤状態で $1.58 \mathrm{~W} \cdot \mathrm{m}^{-1} \cdot \mathrm{K}^{-1}\left(1.36 \mathrm{kcal} \cdot \mathrm{m}^{-1} \cdot \mathrm{h}^{-1} \cdot{ }^{\circ} \mathrm{C}^{-1}\right)$, 乾燥状態で $1.13 \mathrm{~W} \cdot \mathrm{m}^{-1} \cdot \mathrm{K}^{-1}\left(0.98 \mathrm{kcal} \cdot \mathrm{m}^{-1} \cdot \mathrm{h}^{-1} \cdot{ }^{\circ} \mathrm{C}^{-1}\right)$ が得られ，平板比較法では約 $13 \%$ 低い值が得られた。

（3）平板比較法で側面を断熱する効果は大きく, 5 $\mathrm{cm}$ 厚の供試体の方が試験精度はよくなり, $3 \mathrm{~cm}$ 厚は 5 $\mathrm{cm}$ 厚に対して約 $10 \%$ 低い值が得られた。

（4）平板比較法による熱伝導率試験で, 低熱源の温 度制御を行わない場合は, 約 $8 \%$ 低い值が得られた。

（5）前記（2），(3)，(4) の影響で，これまでに 著者らが行った熱伝導率の試験結果は，およそ $28 \%$ 低 い値を得ていたと考えられる.

（6）安山岩を骨材とするコンクリートでは，熱伝導 率が文献 1)，2）に示された一般的な値の $2 / 3$ 程度にな ることがあり，一般的な値をそのまま用いるには注意を 要することが示された.

（7）乾燥状態の熱伝導率は, 湿潤状態に対して約 
$32 \%$ 低い值が得られた.

（8）比熱は湿潤状態で $1.05 \mathrm{~kJ} \cdot \mathrm{kg}^{-1} \cdot \mathrm{K}^{-1}(0.25$ $\left.\mathrm{kcal} \cdot \mathrm{kg}^{-1} \cdot{ }^{\circ} \mathrm{C}^{-1}\right)$, 乾燥状態で $0.85 \mathrm{~kJ} \cdot \mathrm{kg}^{-1} \cdot \mathrm{K}^{-1}(0.20$ $\left.\mathrm{kcal} \cdot \mathrm{kg}^{-1} \cdot{ }^{\circ} \mathrm{C}^{-1}\right)$ であった。

（９）熱拡散率は，湿潤・乾燥両状態で有意な差が認 められずそれぞれ $2.30 \times 10^{-3} \mathrm{~m}^{2} / \mathrm{h}, 2.31 \times 10^{-3} \mathrm{~m}^{2} / \mathrm{h}$ と なった。

（10）乾燥供試体に塗装を施すことにより,熱伝導率, 比熱, 熱拡散率の試験を行うことができ，塗装の影響は 高々 $2 \%$ であった。

今回の試験では, 1 か月程度吸水させた骨材あるいは バイブレーターで十分に締め固めた供試体による試験值 との比較を行わなかった。そのような条件では，熱伝導 率が今回の試験より大きくなる可能性もある.ただし， 実際に現場で施工されるコンクリートでは，骨材の吸水 状態により，さらに低い熱伝導率になり得ることに留意 する必要がある。

謝辞：本論文に一部使用した熱水タンクのデータ は, ピーエスコンクリート株式会社の, また天童タンク および鶴岡タンクのデータは, 天童市水道課, 鶴岡市水 道部および株式会社安部工業所のご協力により得られ た。ここに付記し謝意を表わします.

\section{参 考 文 献}

1）土木学会：昭和 61 年度制定・コンクリート標準示方書・ 設計編, 1986.

2）日本コンクリート工学協会：マスコンクリートのひびわ れ制御指針, 1986 .

3）日本コンクリート工学協会：コンクリート便覧, 技報堂, 1976.

4）空気調和・衛生工学会：空気調和・衛生工学便覧 I 第 10 版, 1981 .

5）日本建築学会：建築学便覧 I, 計画, 第 2 版, 丸善, 1980.

6) 日本機械学会：伝熱工学資料, 第 3 版, 1975.

7）秋田 宏・尾坂芳夫：日射を受けるコンクリート壁の温 度分布に関する考察，土木学会論文集，No. 378, pp. 147 〜 155, 1987 .

8) 岡田 清・六車 熙：コンクリート工学ハンドブック, 朝倉書店, 1981.

9）日本コンクリート工学協会：マスコンクリートの温度応 力研究委員会報告書, 1985 .
10）国分正胤：最新土木材料実験 第 3 版，技報堂， 1980 .

11) ACI Committee 207: Mass Concrete for Dams and Other Massive Structures, ACI J., Vol.67, No.4, pp.273 309, 1970 .

12）徳田 弘・左谷征美：コンクリートの熱特性值の測定と 二, 三の考察, 土木学会論文報告集, No. 212, pp. 89 98, 1973.

13）徳田 弘：コンクリートの熱的性質, コンクリート工学, Vol. 22, No. 3, pp. 29 37, 1984

14）徳田 弘・伊藤 勉：コンクリートの熱抬散率, 熱伝導 率，および比熱について，電力中央研究所技術研究所報 告 (土木·63014), 1964

15）西沢紀昭：コンクリートおよびモルタルの熱拡散率測定 方法に関する実験報告，電研所報，Vol.4, No.2, pp. 66 $\sim 76,1954$.

16）蓮沼 宏，ほか：改訂工業計測便覧，コロナ社，1964.

17）原留美吉・武田義章：物理実験法, 工業調査会, 1980 .

18) Bureau of Reclamation, United States Department of the Interior : Boulder Canyon Project Final Reports, Thermal Properties of Concrete, 1940.

19）武山斌郎·大谷茂盛・相原利雄：伝熱工学, 丸善, 1983.

20）矢川元基・宮崎則幸：有限要素法による熱応力・クリー プ・熱伝導解析, サイエンス社, 1985.

21) Campbell, A.D. and Thorne, C.P. : The Thermal Conductivity of Concrete, Mag. Concrete Research, Vol. 15, No. 43, pp. 39 48, 1963.

22）阿部博俊・青柳征夫：高温下におけるコンクリート構造 物の熱応力に関する問題点, コンクリートジャーナル, Vol. 8, No. 1, pp. 62 67, 1970 .

23）古村副次郎：コンクリートと熱（1）, コンクリート工学, Vol. 17, No. 8, pp. 87 95, 1979 .

24）高崎 䔀 : 本邦産岩石の熱伝導率の測定, 応用物理, Vol. 27, No. 6, pp. 366 370, 1958.

25) Schneider, U. (森永 繁監訳) : コンクリートの熱的性 質，技報堂，1983

26）日本熱物性研究会：熱物性資料集 断熱材編，養賢堂, 1983.

27）棚沢 泰：伝熱率測定器の寸法による誤差について, 機 械学会誌, Vol. 35, pp. 325 332, 1932.

28） Patankar, S. V. (水谷・香月訳)：熱移動亡流れの数值 解析, 森北出版, 1983.

29) Spooner, D. C. : Results of a 'round robin' thermal conductivity test organized on behalf of the British Standards Institution, Mag. Concrete Research, Vol. 32, No.111, pp.117 122, 1980

（1987.1.16 - 受付） 